\title{
The Two Prevalent Genotypes of an Emerging Infectious Disease, Deformed Wing Virus, Cause Equally Low Pupal Mortality and Equally High Wing Deformities in Host Honey Bees
}

\author{
Anja Tehel ${ }^{1, *}$, Quynh Vu ${ }^{2}$, Diane Bigot ${ }^{1}$, Andreas Gogol-Döring ${ }^{3,4}$, Peter Koch ${ }^{4}$, \\ Christina Jenkins ${ }^{1}$, Vincent Doublet ${ }^{1,5}{ }^{(D}$, Panagiotis Theodorou ${ }^{1}$ and Robert Paxton and $^{1,3, *(D)}$ \\ 1 General Zoology, Institute for Biology, Martin Luther University Halle-Wittenberg, Hoher Weg 8, \\ 06120 Halle (Saale), Germany; bigot.diane@gmail.com (D.B.); cej.jenkins@gmail.com (C.J.); \\ vincent.bs.doublet@gmail.com (V.D.); panatheod@gmail.com (P.T.) \\ 2 Cuu Long Delta Rice Research Institute, Can Tho City 94709, Vietnam; vquynh@gmail.com \\ 3 German Centre for Integrative Biodiversity Research (iDiv) Halle-Jena-Leipzig, Deutscher Platz 5e, \\ 04103 Leipzig, Germany; andreas.gogol-doering@mni.thm.de \\ 4 Technische Hochschule Mittelhessen, University of Applied Sciences, Wiesenstrasse 14, \\ 35390 Gießen, Germany; Koch.Peter@gmx.de \\ 5 Institute of Evolutionary Biology, University of Edinburgh, Charlotte Auerbach Road, \\ Edinburgh EH9 3FL, UK \\ * Correspondence: anja.tehel@student.uni-halle.de (A.T.); robert.paxton@zoologie.uni-halle.de (R.P.); \\ Tel.: +49-345-55-26507 (A.T.); +49-345-55-26500 (R.P.)
}

Received: 24 January 2019; Accepted: 27 January 2019; Published: 29 January 2019 updates

\begin{abstract}
Deformed wing virus (DWV) is an emerging infectious disease of the honey bee (Apis mellifera) that is considered a major cause of elevated losses of honey bee colonies. DWV comprises two widespread genotypes: the originally described genotype $\mathrm{A}$, and genotype $\mathrm{B}$. In adult honey bees, DWV-B has been shown to be more virulent than DWV-A. However, their comparative effects on earlier host developmental stages are unknown. Here, we experimentally inoculated honey bee pupae and tested for the relative impact of DWV-A versus DWV-B on mortality and wing deformities in eclosing adults. DWV-A and DWV-B caused similar, and only slightly elevated, pupal mortality (mean 18\% greater mortality than control). Both genotypes caused similarly high wing deformities in eclosing adults (mean 60\% greater wing deformities than control). Viral titer was high in all of the experimentally inoculated eclosing adults, and was independent of wing deformities, suggesting that the phenotype 'deformed wings' is not directly related to viral titer or viral genotype. These viral traits favor the emergence of both genotypes of DWV by not limiting the reproduction of its vector, the ectoparasitic Varroa destructor mite, in infected pupae, and thereby facilitating the spread of DWV in honey bees infested by the mite.
\end{abstract}

Keywords: pathology; virulence; positive single-strand RNA virus; DWV; genotype A; genotype B; Apis rhadbovirus-1; Apis mellifera

\section{Introduction}

Honey bees (Apis mellifera) are globally the most important commercial pollinator of crops [1], as well as playing an important role in the pollination of wild plants [2]. Although the world stock of colonies has grown over the past half century in response to increasing pollinator-dependent agricultural production $[3,4]$, honey bees in the temperate Northern Hemisphere have suffered increasing colony mortality in the past two decades [5-7]. Multiple explanations for elevated colony 
losses have been proposed, chiefly comprising: diverse forms of habitat degradation, parasites, pesticides, and interactions among all three factors $[4,8,9]$. Surveys of pests and pathogens of honey bees in the temperate Northern Hemisphere have highlighted the exotic and invasive ectoparasitic mite, Varroa destructor, which is a native ectoparasite of the S. and E. Asiatic honey bee Apis cerana, and the emerging infectious disease agent, Deformed wing virus (DWV), together being a major cause of elevated colony loss [10-18].

The invasion of honey bee populations by $V$. destructor leads to a greatly increased prevalence (proportion of infected individuals or colonies) and intensity of infection (viral titer per individual) of DWV $[19,20]$. DWV is a positive single-stranded RNA virus of the family Iflaviridae (order Picornaviruses) that has long been associated with A. mellifera [21]. Although transmission routes of DWV among honey bees are diverse [22-26] (reviewed in [27]), V. destructor is a highly efficient vector of DWV when it parasitizes honey bee pupal stages [28-32], leading to its emergence in the presence of $V$. destructor. Although DWV may also replicate within $V$. destructor [24,30,31,33] (summary in [34]), enhancing its transmission, other evidence argues against the within-mite replication of DWV [32,35]. Regardless of whether $V$. destructor acts as a mere vector of DWV or whether the virus also replicates in the vector, the direct effects of DWV per se on honey bees have been difficult to separate from those of feeding by $V$. destructor on host pupae during metamorphosis, but include deformed wings, shortened abdomen, discoloration, and the reduced lifespan of metamorphosing adult hosts $[24,30,36,37]$ (reviewed in [38]). Experimental infection has demonstrated that DWV alone causes crippled wings [31] and reduced adult lifespan [17], including an acceleration of the temporal polyethism schedule of workers [39,40]. Less is known about the impact of DWV on honey bee pupae [29], although it is reported to cause elevated brood mortality [41].

DWV is arguably the most intensively studied virus of honey bees, from genetic, molecular, and biological characterization $[27,42]$ through to the high-resolution tertiary structure of its virion capsid [43]. These studies refer to the originally described variant of DWV, which is now termed DWV genotype A (DWV-A) [17], and for which a molecular clone has been developed [44]. In 2004, a second major variant of DWV (genotype B) was described from $V$. destructor and associated honey bees [33]. Originally termed Varroa destructor virus-1, DWV-B has ca. $84 \%$ sequence similarity to DWV-A [33]. Following convention in virology to term variants with $>7.5 \%$ sequence dissimilarity as distinct genotypes [45], these two DWV variants have been termed: genotypes A and B [46-48]. Recombinants between genotypes A and B have often been reported [49-54], suggesting that recombination is frequent, or that recombinants have a selective advantage over parental genotypes. DWV has also been considered to represent a quasispecies [27]. Although originally described in the Netherlands [33], DWV-B seems to be increasing in prevalence and distribution, though alternatively it may have gone under-recorded or unrecorded. It has now been reported in Great Britain [17,51,55,56], Belgium [40], the Caucasus [57], France [58], Germany [18], Israel [50], Kenya [59], South Africa [60] and the United States (USA) [61], where sampling in 2010 and again in 2016 suggests that DWV-B has increased rapidly in prevalence. A third variant, which has been termed DWV-C, has been identified [47], and other genotypes of DWV may exist [62].

Central to understanding disease emergence is the ability to define the genetic variants of a pathogen in terms of their ability to cause harm to their hosts, which is termed virulence, and is often correlated with their ability to replicate in hosts [63]. We have formerly shown though experimental inoculation that DWV-B has elevated virulence in adult honey bees compared to DWV-A [17], shortening adult lifespan $[39,40]$ and leading to overwinter colony decline during the season when, in temperate regions, colonies are devoid of brood (larvae and pupae) [18]. We have also found that DWV-B replicates faster than DWV-A in adult hosts [17], which is the most parsimonious explanation for why the former is more virulent that the latter in adult hosts. On the contrary, earlier studies have suggested that DWV-B may exclude DWV-A [46], whilst Gisder et al. [64] have recently suggested that DWV-A and DWV-B are more virulent, or replicate most efficiently or to higher titers in host honey bee pupae and vector $V$. destructor mites, respectively. An understanding of the epidemiology of DWV 
and its genotypes requires knowledge of their comparative impact on honey bee pupae. Firstly, this is because pupae are present in a colony for much of the year (early spring to autumn) [65], and they are likely pivotal in accounting for viral prevalence and the intensity of infection in a colony [66]. Secondly, this is because the major DWV vector $V$. destructor only reproduces on host pupae [38], when it readily transmits virus between hosts [28-30].

Using a conceptually simple experimental design coupled with high-resolution next-generation sequence data of viral inocula and resultant host bees, we compared the virulence of DWV-A and DWV-B in metamorphosing honey bees in terms of pupal mortality, wing deformities, and viral titer. We conclude that DWV genotypes A and B differ little in their impact on host pupae, which may help to explain why both have emerged to become major pathogens of honey bees.

\section{Materials and Methods}

\subsection{Source of Honey Bees}

Honey bee pupae for experiments were taken from two colonies (colony one, colony two) in the General Zoology apiary at Martin Luther University Halle-Wittenberg, Germany, which were originally purchased as the subspecies A. mellifera carnica and are typical for beekeeping in the region. Both were inspected visually for $V$. destructor mites and by quantitative real-time PCR (qPCR) for eight common viral targets: DWV-A, DWV-B, Acute bee paralysis virus (ABPV), Black queen cell virus (BQCV), Chronic bee paralysis virus (CBPV), Israeli acute paralysis virus (IAPV), Sacbrood virus (SBV), and Slow bee paralysis virus (SBPV), using the primers given in McMahon et al. [56] (for all viruses except CBPV) and [67] (for CBPV) using methods described below (Section 2.4). Varroa destructor mites were not seen, and viruses were not detected in colonies at a threshold cycle $(\mathrm{Ct})$ of 35 cycles or less $(\mathrm{Ct}>35)$, which is a threshold that minimizes the rate of false positives [68].

White-eyed worker pupae were uncapped and carefully removed from frames of brood using fine forceps, and then kept in Petri dishes in incubators at $35{ }^{\circ} \mathrm{C}$ and $50 \%$ relative humidity (RH) for one to two hours. Pupae that showed signs of damage (blackening) were rejected, as we assumed that we had physically damaged them during removal from their natal cells. Surviving pupae were immediately used for the propagation of genotype-specific DWV inocula or in inoculation experiments.

\subsection{Virus Propagation and Assessment of Inocula}

To propagate a DWV-A inoculum and a DWV-B inoculum for experiments, we injected one $\mu \mathrm{L}$ of the genotype-specific inocula of McMahon et al. (2016), which was originally extracted from an adult, heavily virus-infected honey bee with normal wings from Great Britain (DWV-A) and Germany (DWV-B), into white-eyed pupae taken from another, virus-free colony at the same source apiary as colonies one and two (Figure 1a). After three to five days, pupae were harvested in groups of two to five, crushed in $0.5 \mathrm{M}$ of cold potassium phosphate buffer (PPB $\mathrm{pH} 8.0$ ), and the resulting homogenate was screened for viruses by qPCR using the methods described below (Section 2.4). We screened our new inocula for the presence of DWV-A and DWV-B as well as six other common honey bee RNA viruses: ABPV, BQCV, CBPV, IAPV, SBV, and SBPV, using the primers described above (Section 2.1). We always generated the correct genotype-specific DWV inoculum from the original inocula [17], although occasional contamination by BQCV caused us to reject a small number of batches of pupal homogenates. As BQCV is at very high prevalence in honey bees [56], it is unsurprising that pupae were occasionally infected with this virus, and that their homogenates were hence rejected by us when generating DWV-inocula. Uninjected white-eyed pupae were treated and screened for viruses in the same way as the pupae that were used to generate viral inocula. As these uninjected pupae were devoid of virus, we used them to generate a control inoculum that was identical to viral inocula, but for the lack of virus. 


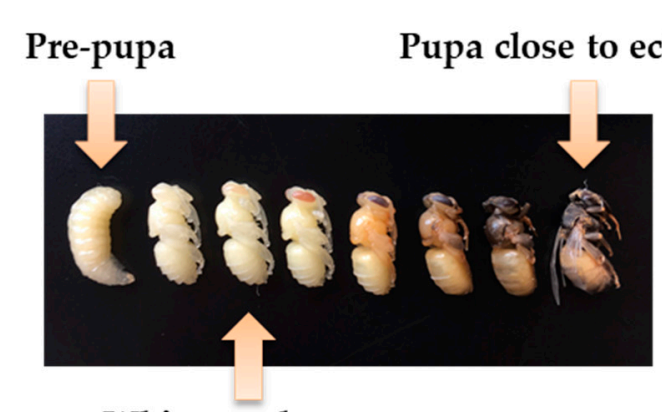

White-eyed pupa

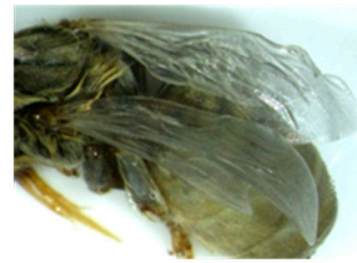

Normal wings

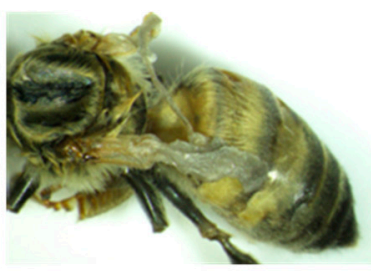

Deformed wings

(a)

(b)

Figure 1. (a) White-eyed pupa used to generate deformed wing virus (DWV) inocula and in inoculation experiments, with prepupae to the left, and more advanced pupal stages to the right (each stage separated by ca. 24 hours); (b) left, normal winged adult; right, adult with deformed wings.

For the absolute quantification of DWV-A or DWV-B in our inocula, external DNA standards were generated using primers in [56] (stand' curve primers), which were quantified on an Epoch spectrophotometer, and then used to generate a dilution series $\left(10^{-1}-10^{-8}\right)$ for each DWV genotype that covered the complete range of $\mathrm{Ct}$ values in our inocula and our experimental material. Although RNA standards are considered preferable [48], our approach to viral quantification follows the standard methods in bee-virus research [68], and seems robust, because we have found that the results from them reflect those from the next-generation sequence data that was generated using the same viral samples [17]. The dilution series was amplified by qPCR using specific primers for DWV-A or DWV-B to give duplicate standard curves for DWV-A and DWV-B, with our inocula amplified on the same PCR plate. Primer efficiencies were $90-92 \%$ for a DWV-A RdRp primer pair, and $98-100 \%$ for a DWV-B $R d R p$ primer pair, and correlation coefficients $\left(R^{2}\right) \geq 0.988$. Our inocula containing only DWV-A or only DWV-B at known concentrations were aliquoted and stored at $-80^{\circ} \mathrm{C}$ for use in experiments, as was our control inoculum devoid of virus.

To precisely check the genetic makeup of our DWV inocula, we extracted RNA from them using methods in Appendix A, with the inclusion of a DNAse step. RNA was submitted to commercial mRNA library preparation and ultra-deep next-generation sequencing (NGS) on an Illumina platform (GATC Biotech) as two separate libraries. Sequenced reads were mapped to the A. mellifera reference genome (v. 4.5), and to two DWV-A and DWV-B reference genomes (GenBank Accession Numbers NC_004830.2 and NC_006494.1, respectively) using Bowtie 2 [69] (each read was only scored once). Mapped reads were then assigned to A. mellifera, DWV-A or DWV-B. Reads that were mapped to both DWV genotypes were counted as DWV-A or DWV-B in the same proportion as the reads that could be uniquely assigned to either DWV-A or DWV-B; they were spread equally across the DWV genome. We then assembled DWV reads using IVA [70] under the default settings of software that is specifically designed for the de novo assembly of RNA virus genomes, to generate contigs of DWV. To do so, we used all of the DWV NGS reads mapped by Bowtie 2 (above), and any additional DWV reads identified by the de novo assembly of the remaining reads when screening for other viruses, as described in Appendix B. Each contig was then included in a phylogenetic tree using PhyML [71] to visualize its relationship to DWV-A and DWV-B, and identify potential A-B recombinants. Details of the screening of NGS libraries for other viruses, including the detection of full-length Apis rhadbovirus-1 (BRV-1) [72,73], and other contaminants are given in Appendix B. NGS data files are accessible under BioProject ID PRJNA515220. 


\subsection{Viral Inoculation and Virulence}

To test the impact of viral genotype on pupal development, we injected one $\mu \mathrm{L}$ of viral inoculum per white-eyed pupa (Figure 1a) directly into its hemolymph between its second and third abdominal tergites using a Hamilton syringe (hypodermic needle outer diameter: $0.235 \mathrm{~mm}$ ), simulating viral transmission by $V$. destructor. Viral inocula were firstly diluted in $0.5 \mathrm{M}$ of cold PPB (pH 8.0) to final concentrations of $10^{2}$ and $10^{4}$ genome equivalents per $\mu \mathrm{L}$, as quantified by qPCR. Then, one $\mu \mathrm{L}$ containing $10^{2}$ or $10^{4}$ of DWV-A, $10^{2}$ or $10^{4}$ of DWV-B, or $10^{2}$ or $10^{4}$ of an equal mix of DWV-A plus DWV-B was injected into a pupa. Other pupae were injected with the control inoculum devoid of virus, representing a control group. To avoid cross-contamination, syringes were cleaned after each use, and different syringes were used for inocula A, B, the mix, and control. Additional pupae were kept uninjected to determine the impact of injection per se on early pupal survival and wing deformation (Figure 1b). Each treatment group comprised 16 pupae from each of the two source colonies, and every treatment was administered on the same day and by the same person.

Pupae from all of the treatments were placed in 96-well microtiter plates, which were placed vertically so that pupae were horizontal, and maintained in incubators at $35^{\circ} \mathrm{C}$ and $50 \% \mathrm{RH}$ to monitor pupal development. At 24 hours post-inoculation (p.i.), 10.4\% (25 of 240) injected pupae had died, whereas zero uninjected pupae (0 of 32) had died. As control-injected and viral-injected pupae died at the same rate in the first 24 hours (difference in proportions, Fisher exact test $p=0.793$ ), we assumed that the cause of mortality was physical injury by the hypodermic needle, and not virus inoculum per se. Therefore, the pupae that died within 24 hours p.i. were eliminated from further analysis.

Mortality from day two p.i. through to eclosion was recorded daily as a measure of viral virulence. At day six to day seven p.i., adult workers eclosed. Then, the wing morphology of eclosing adults was inspected visually to determine the impact of virus on wing deformation (Figure 1b), which was another measure of viral virulence. To assess whether viral titer was related to wing deformation or the viral genotype, eclosing adult bees were stored at $-80^{\circ} \mathrm{C}$ for viral quantification exactly as described above (Section 2.2).

To check that viral inocula were viable and the virus was replicating following injection, 24 additional pupae were injected as above with $10^{2}$ or $10^{4}$ DWV-A or $10^{2}$ or $10^{4}$ DWV-B and frozen either on day zero (immediately after injection) or on day three p.i.; then, viral titer was quantified as described above (Section 2.2). Further, in order to test that the virus in the inocula that we had injected into pupae had actually replicated, we again resorted to ultra-deep NGS analysis of one eclosing adult each of a pupa injected with DWV-A (individual pupal code: D4-DWV-A) and a pupa injected with DWB-B (individual pupal code: V4-DWV-B) with the same methods and bioinformatics algorithms used to analyze viral inocula, as described in Section 2.2 and in Appendix B. NGS data files are accessible under BioProject ID PRJNA515220.

\subsection{RNA Extraction and Detection of Virus}

We used standard methods for RNA extraction and cDNA synthesis [68] (and see Appendix A):

(i) when testing whether honey bee source colonies were free of virus,

(ii) when screening pupal homogenates (our inocula) for RNA viruses and quantifying DWV titer in them,

(iii) when quantifying viral titers in adult worker bees arising from inoculation experiments, and

(iv) when quantifying viral titers in pupae at zero and three days p.i.

For viral detection, qPCRs were performed for each sample in a Bio-Rad C1000 thermal cycler (Bio-Rad, Munich, Germany), using SYBRgreen Sensimix (Bioline, Luckenwalde, Germany) and the primers described above (2.1 Source of Honey Bees) with the following program: five minutes at $95^{\circ} \mathrm{C}$, followed by 40 cycles of 10 seconds at $95^{\circ} \mathrm{C}, 30$ seconds at $57{ }^{\circ} \mathrm{C}$ and 30 seconds at $72{ }^{\circ} \mathrm{C}$. We used a $\mathrm{Ct}$ threshold of 35 to define a sample as positive for a virus $(\mathrm{Ct}<35)$. We ran quality control checks on 
each qPCR 96-well reaction plate to ensure that we had amplified and quantified the correct target (Appendix A).

For absolute viral quantification, duplicate qPCRs were performed for each sample, and the mean $\mathrm{C} t$ value was used. All of the qPCR plates contained a dilution series covering eight orders of magnitude $\left(10^{-1}-10^{-8}\right)$ of an external DNA standard (see Section 2.2), which we used to generate the calibration curves for the quantification of the virus target. qPCRs were repeated for samples whose duplicate $\mathrm{Ct}$ values differed by $>0.5$.

\subsection{Statistical Analyses}

Generalized linear mixed-effects models (GLMMs) with binomial error structure were used to analyze the overall effect of viral inoculation on bee mortality and wing deformities; Tukey post hoc tests were then used for pairwise comparisons between viral treatments. We used GLMMs with Poisson error structure to test whether the wing deformities in emerging adults were associated with the higher viral titer in each treatment. As the focus of our study was on differences between viral genotypes, colony was used as a random factor in all of the mixed-effect models. Additionally, we used generalized linear models (GLMs) with Poisson error structure to test for differences in viral titer between the two DWV genotypes. All of the model analyses were performed using the R package lme4 v.1.0-6 [74]. Post-hoc tests were performed using the R package multcomp [75]. If overdispersion was detected in GLMs and GLMMs, we used a quasibinomial and a quasi-Poisson model. All of the model (GLMM and GLM) assumptions were checked visually, and were found to conform to expectations (e.g. normality of the distribution of residuals, homogeneity of variances, linearity). All of the analyses were performed in R v 3.5.0 [76], in which GLM is included in the R base statistics functions.

\section{Results}

\subsection{Analysis of Inocula}

By qPCR, we detected only DWV-A in the DWV-A inoculum, and only DWV-B in the DWV-B inoculum. When we mapped our NGS data to DWV reference sequences using Bowtie 2, we also found each inoculum to contain its own genotype with very little contamination of the other genotype (see Appendix B and Table S1). We detected a small amount of Apis rhadbovirus-1 (BRV-1) [72,73] in the assembled contigs of each inoculum's NGS dataset (Table S1), but only a few fragments of the other putative viruses or uncharacterized Eukaryote genes $(<0.33 \%)$, and none of DWV genotype $C$, which is another described genotype of DWV [46-48]. To test for the impact of BRV-1 in the inocula on our experiment, we analyzed 36 eclosing adults that had been experimentally inoculated as pupae by our inocula using qPCR with the BRV-1 primers and the protocol of [72]. In only one of 36 bees could we detect a positive signal, which was albeit weak $(\mathrm{Ct}=32.15)$, suggesting a low titer of BRV-1 in this individual, and little contamination of our infection experiment by BRV-1.

To confirm that experimental inocula had replicated in pupae and explore further the possible replication of BRV-1 in our experiment, we subjected two additional experimentally inoculated and eclosing adult bees to ultra-deep NGS analysis exactly as described above as two separate libraries (one library of a DWV-A experimentally inoculated bee, and one library of a DWV-B experimentally inoculated bee). We repeated our NGS data analyses as described above, and revealed each bee to contain the DWV genotype with which it had been inoculated with very little contamination of the other genotype, or of recombinants between the genotypes, or of other putative viruses or uncharacterised Eukaryote genes (see Appendix B and Table S2). The bee inoculated with DWV-A had a trace of BRV-1 reads $(0.000007 \%$ of reads), whilst the bee inoculated with DWV-B was completely devoid of BRV-1 reads (Table S2). Therefore, we considered BRV-1 not to have impacted our experiment; our analyses suggest that BRV-1 may not be pathogenic for $A$. mellifera pupae.

Our IVA-bioinformatics software de novo assemblies of the DWV reads from our NGS data revealed only a single full-length genome contig per library, corresponding to DWV-A for inoculum-A (and the 
pupa inoculated with A), and corresponding to DWV-B for inoculum-B (and the pupa inoculated with B). NGS read coverage of the DWV-A and DWV-B inocula was consistently high across the genome (Figure S1). The DWV-A contig of our DWV-A inoculum differed by 263 bp (263 mismatches, 97.7\% sequence identity) and the DWV-B contig of our DWV-B inoculum by 78 bp (77 mismatches and one insertion, 99.3\% sequence identity) from the respective GenBank reference sequences (Table S3). Each genotype varied in sequence by $<0.5 \%$ across its genome (Figure S2).

Inocula full-length genome contig sequences (Figures S3, S4) differed minimally from those of [17], from which they were derived (one single-nucleotide protein (SNP) difference in DWV-A, three SNP differences in DWV-B; Table S3). Furthermore, full-length genome contig sequences of viral NGS reads derived from adult hosts differed minimally from those of inocula with which they had been experimentally inoculated as white-eyed pupae (two SNP differences in DWV-A, five SNP differences in DWV-B; see Table S3).

In addition to the full-length genome DWV-A or DWV-B contigs that were generated by the IVA assemblies of DWV-A (the DWV-A inoculum and the DWV-A inoculated pupa) and DWV-B (the DWV-B inoculum and the DWV-B inoculated pupa), partial genome contigs were also generated from two of the four NGS datasets. The pupa inoculated with DWV-A (D4-DWV-A) contained four short DWV-B contigs, whilst two short DWV-A contigs were generated from the DWV-B inoculum (Figure S5). These short contigs (Figures S3 and S4) mirror the results from mapping the same reads using Bowtie 2 to reference sequences, with a very small number of DWV-B reads in the DWV-A experimental material, and a very small number of DWV-A reads in the DWV-B experimental material (Tables S1 and S2). Visual comparison by alignment (Figure S5) and phylogenetic analysis of contig sequences generated by IVA (Figure S6) suggest that our inocula and experimentally inoculated pupae harboured little or no A-B recombinants. These patterns also suggest that the virus we injected into a pupa had replicated and that viral genotype varies little during the course of an infection.

The sequence similarity of the genome of our DWV-A inoculum to the genome of our DWV-B inoculum was $84.4 \%$ (1691 mismatches, 20 insertions and deletions), which was a difference that was considerably higher than the genetic variability within an isolate of a genotype $(<0.5 \%$, see Figure S2), or of a single genotype across the course of an infection (Table S3). The two viral inocula did not form a single, interconnected mutant cloud or quasispecies, and remained consistently distinct across the course of a host infection.

\subsection{Impact of Inoculation on Honey Bee Pupae}

In our initial check that viral inocula were viable and the virus was replicating following injection, we did not detect any virus in the pupae by qPCR at day zero p.i. (Figure S7), which was likely because the virus amount was too small to detect. However, at day three p.i., pupae contained high viral titers of the genotype with which they had been injected (DWV-A mean \pm SE $=1.16 \times 10^{12} \pm 1.66 \times 10^{11}$; DWV-B mean $=1.07 \times 10^{11} \pm 6.21 \times 10^{10}$; Figure S7), indicating that inocula were viable and the virus was replicating well. Additionally, at day three p.i., there were no significant differences in viral titer between pupae injected with either $10^{2}$ or $10^{4}$ genome equivalents (quasi-Poisson GLM; DWV-A, $\mathrm{z}=$ $0.120, p=0.904 ;$ DWV-B, $\mathrm{z}=-0.742, p=0.458$; Figure S7), which was possibly because viral replication had reached an asymptote, and pupae had reached their viral carrying capacity. Henceforth, we combined the data of the two viral quantities $\left(10^{2}\right.$ and $10^{4}$ genome equivalents) for each viral treatment. We note that, at day three p.i., DWV-A showed a slightly higher titer than DWV-B (GLM, z = -2.688, $p=0.007$; Figure S7).

The inoculation of white-eyed pupae with virus led to a significantly higher mortality (mean 29\%) compared with control-injected pupae (mean 11\%; GLMM; $\chi^{2}=4.140, p=0.041$; Figure 2). Differences among viral treatments (inocula $\mathrm{A}, \mathrm{B}$, and $\mathrm{A}+\mathrm{B}$ ) were minor and statistically insignificant (Tukey post hoc tests; $\mathrm{B}$ versus $\mathrm{A}: \mathrm{z}=-0.307, p=0.759 ; \mathrm{AB}$ versus $\mathrm{A}: \mathrm{z}=0.041, p=0.968$; $\mathrm{AB}$ versus $\mathrm{B}: \mathrm{z}=-0.346$, $p=0.730$; Figure 2), suggesting that both A and B genotypes of DWV have an equal and subtle effect in elevating pupal mortality by $18 \%$ above control. We note that the random term 'colony' was significant 
in these analyses (likelihood ratio test; $\chi^{2}=9.739, p=0.001$ ), which was likely because virus-induced pupal mortality was lower in colony two compared to colony one (Figure S8).

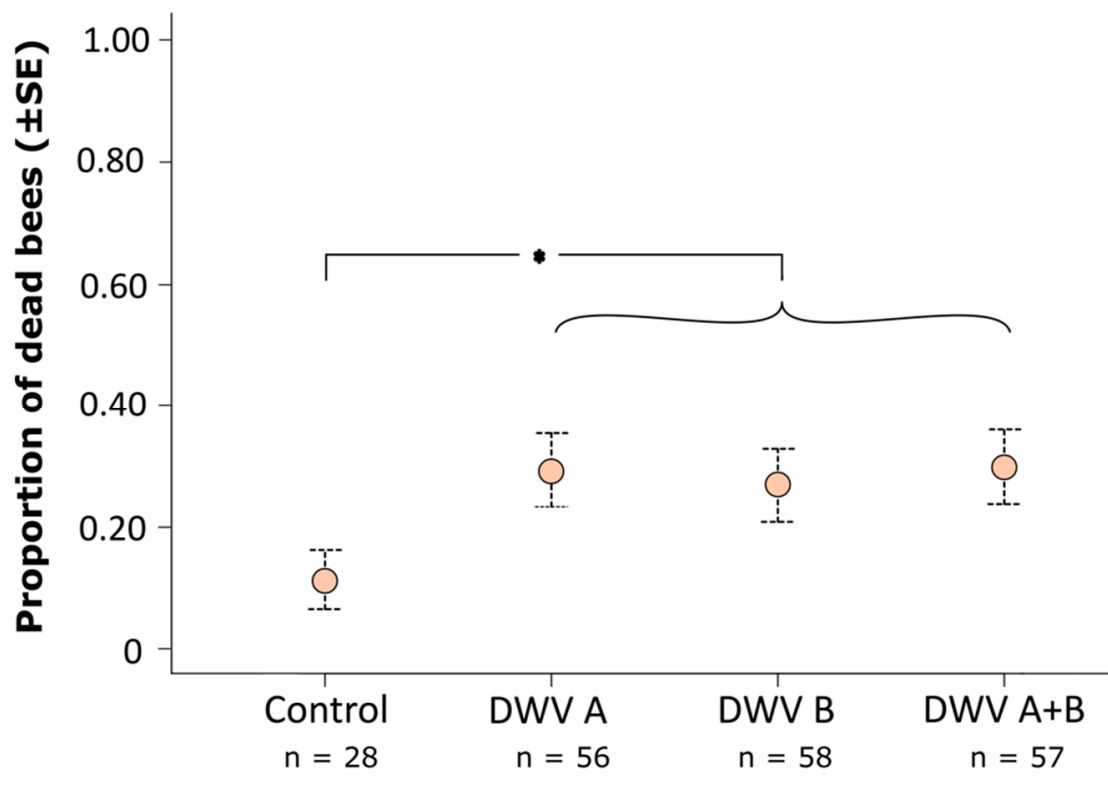

Treatments

Figure 2. Mean proportion of dead honey bee pupae inoculated at the white-eyed stage with a control solution (virus-free extract of bees), deformed wing virus A (DWV-A) inoculum, deformed wing virus B (DWV-B) inoculum, or simultaneously DWV-A and DWV-B inocula, and dying before or at eclosion. DWV-inoculated bees suffered significantly higher mortality (mean 29\%) than control bees (mean 11\%; GLMM; $\chi^{2}=4.140, p=0.041$ ) but mortality did not differ between virus-inoculated treatments ${ }^{*}$, Tukey post hoc pairwise comparisons, all $p>0.05) ;{ }^{*}, p<0.05$.

For the bees that survived through to eclosion, $83 \%$ of the virus-injected bees possessed one or more deformed wings, whereas only $23 \%$ of the control-injected bees exhibited deformed wings (Figure 1b), which was a statistically significant difference (GLMM; $\chi^{2}=36.202, p<0.001$; Figure 3). Differences in the proportion of eclosing bees with wing deformities among viral treatments (inocula $\mathrm{A}, \mathrm{B}, \mathrm{A}+\mathrm{B}$ ) were small and statistically non-significant (Tukey post hoc tests; $\mathrm{B}$ versus $\mathrm{A}: \mathrm{z}=-1.345$, $p=0.179 ; \mathrm{AB}$ versus $\mathrm{A}: \mathrm{z}=0.631, p=0.528 ; \mathrm{AB}$ versus $\mathrm{B}: \mathrm{z}=1.883, p=0.060$; Figure 3 ). The random term 'colony' was non-significant in this analysis (likelihood ratio test; $\chi^{2}=1.238, p=0.266$ ); bees from both colonies suffered equally from wing deformations (Figure S8). 


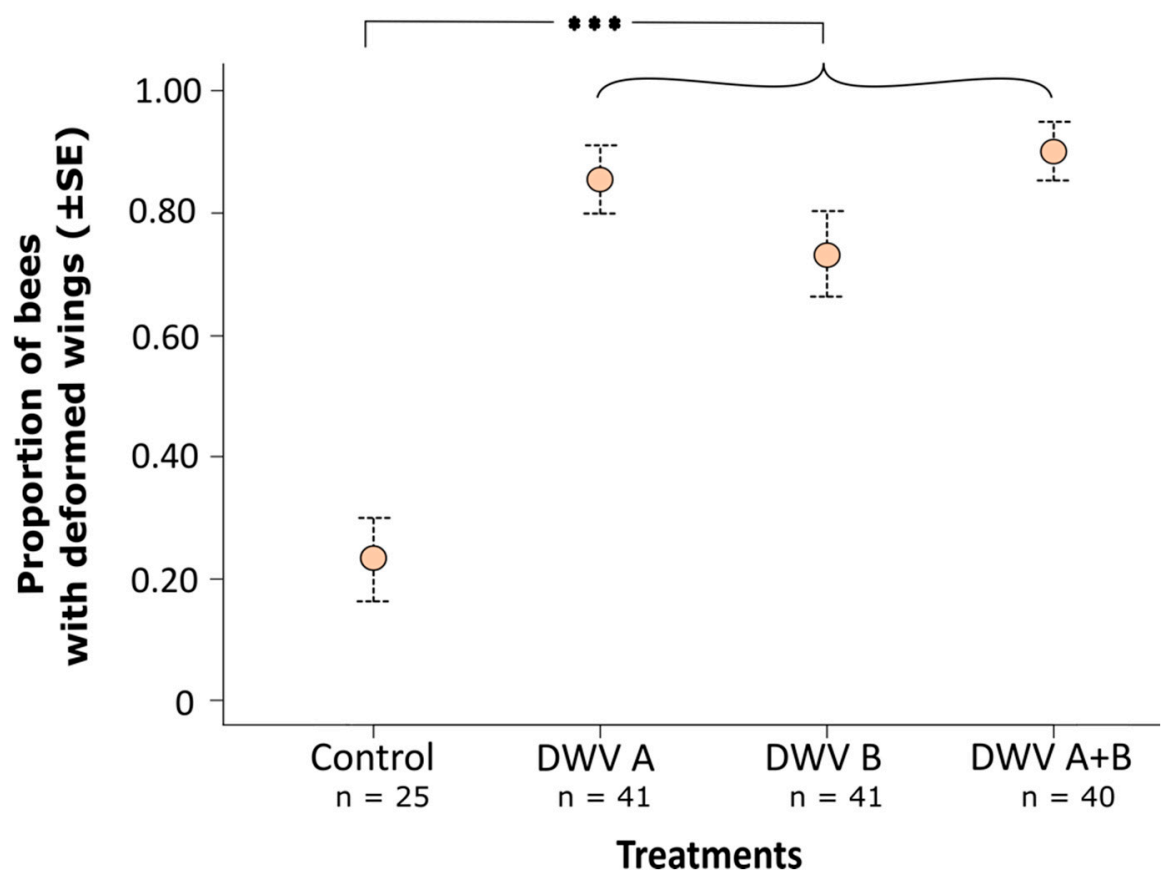

Figure 3. Mean proportion of successfully eclosing honey bee adults with deformed wings that as white-eyed pupae had been inoculated with a control solution (virus-free extract of bees), DWV-A inoculum, DWV-B inoculum, or simultaneously DWV-A and DWV-B inocula; virus-inoculated bees more frequently eclosed with wing deformities (mean 83\%) than control bees (mean 23\%; GLMM; $\left.\chi^{2}=36.202, p<0.001\right)$, but the probability of wing deformation did not differ between virus-inoculated treatments (Tukey post hoc pairwise comparisons, all $p>0.05$ ); ${ }^{* * *}, p<0.001$.

Bees eclosing with normal wings did not differ in viral loads from those eclosing with deformed wings for each of the three virus treatment groups (A, B, A+B; quasi-Poisson GLMM, DWV-A treatment with normal versus deformed wings, $\mathrm{z}=0.152, p=0.879$; DWV-B treatment with normal versus deformed wings, $\mathrm{z}=0.180 p=0.238$; DWV A+B treatment [total viral load] with normal versus deformed wings, $\mathrm{z}=-0.186, p=0.852$; Figure 4). Control-injected bees had only background titers of virus (Figure 4). For the DWV A+B treatment, the viral loads for each of the genotypes also did not differ between bees eclosing with normal wings versus those eclosing with deformed wings (quasi-Poisson GLMM treatment DWV A+B; DWV-A z $=-0.139, p=0.889 ; \mathrm{DWV}-\mathrm{B} z=-0.199, p=0.842 ;$ Figure 4). This pattern did not change when analyzing the viral load solely by viral genotype rather than by experimental treatment (Figure S9). Therefore, wing deformation was independent of viral load or viral genotype under our experimental paradigm. 


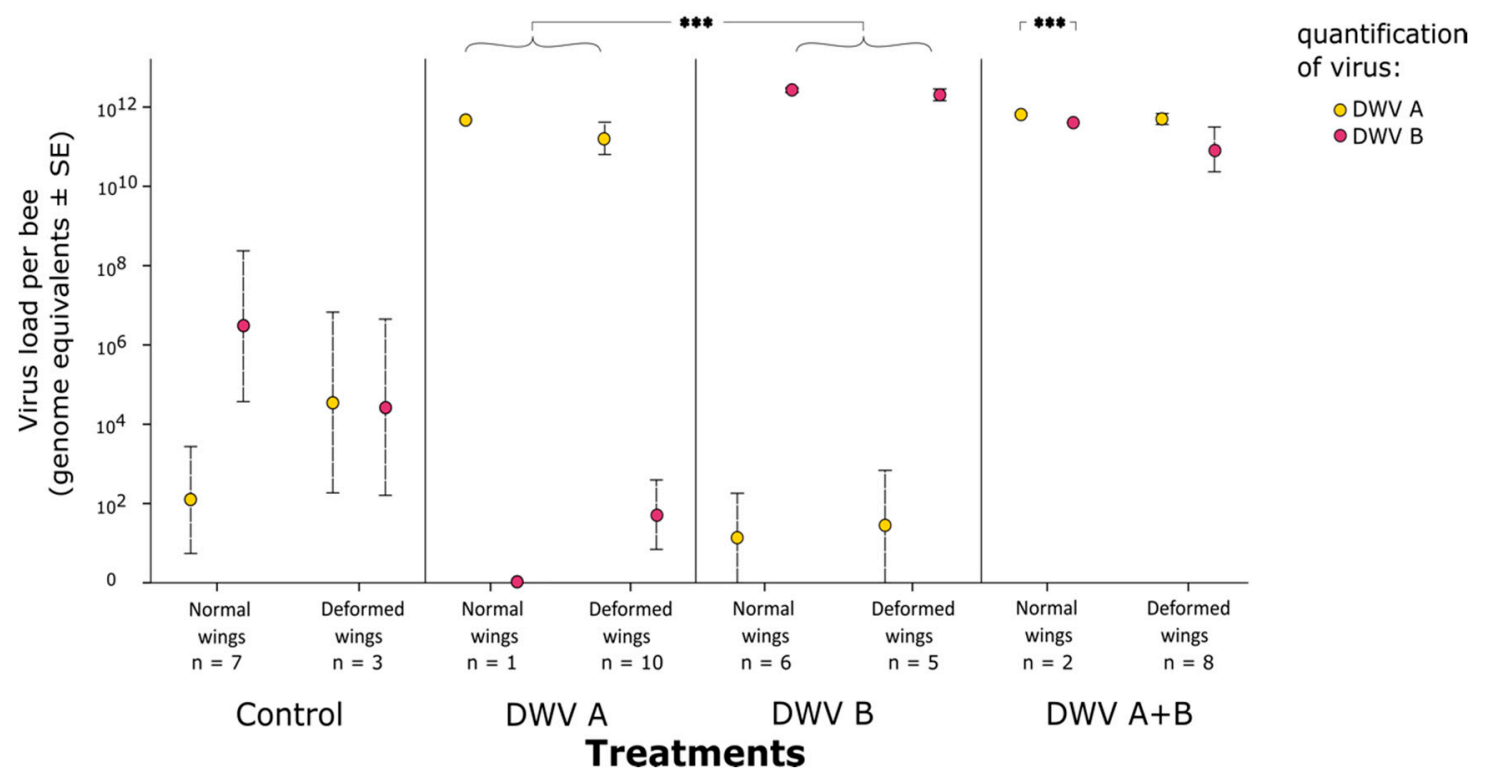

Figure 4. Mean DWV titers in eclosing honey bee adults that as white-eyed pupae had been inoculated with control (virus-free pupal extract), DWV-A inoculum, DWV-B inoculum, or simultaneously DWV-A and DWV-B inocula. Viral titers did not differ within a viral treatment for bees emerging with normal versus deformed wings (GLMM $p>0.05$ ). Bees inoculated with DWV-B had a higher titer of DWV-B than the bees inoculated with DWV-A had of DWV-A (GLMM $p<0.001)$, which was a pattern that was reversed for the bees simultaneously inoculated with DWV A+B that emerged with normal wings $($ GLMM $p<0.001) ;{ }^{* * *}, p<0.001$.

DWV-B replicated to a higher titer in eclosing bees that had the DWV-B treatment than DWV-A did in eclosing bees that had the DWV-A treatment (quasi-Poisson GLMM; DWV-A versus DWV-B: $\mathrm{z}=$ 3.713, $p<0.001$; Figure 4). The difference in titer was modest, ca. twofold (DWV-A mean $1.20 \times 10^{12}$; DWV-B mean: $2.68 \times 10^{12}$ ).

We note that the DWV-B titer in the adults that had received DWV A+B treatment and successfully eclosing with normal wings was slightly although significantly lower than the DWV-A titer in the same bees (quasi-Poisson GLMM; DWV-A versus DWV-B: $\mathrm{z}=-5.155, p<0.001$; Figure 4). However, differences in titer were small (Figure 4), and the result is based on only $n=2$ successfully emerging bees. Therefore, we caution against the over-interpretation of this result.

\section{Discussion}

Using a controlled laboratory experiment, we show that DWV genotype B is no different in virulence for host honey bee pupae than DWV genotype A; both genotypes caused subtly elevated pupal mortality, and both caused considerably elevated wing deformities in eclosing adult workers. However, in single-genotype infections, DWV-B did replicate to a slightly higher titer than DWV-A in pupae that reached adulthood.

McMahon et al. [17], using genetically near-identical inocula to those employed in our experiments, found that DWV-B was more virulent than DWV-A when injected into honey bee adults, replicating faster and killing adults sooner than DWV-A. Although one observational study has suggested that DWV-B may be less virulent than DWV-A [46], the higher virulence of DWV-B has since been independently supported by others through the experimental infection of adult honey bees in Belgium [40]. In contrast to our findings, a recent experimental study [64] found that DWV reduced in virulence following a single passage through a host pupa, and that the viral variant switched from DWV-B to DWV-A in passing through a second pupa. Our experimental data did not show the same result, and we did not observe an oscillation between genotypes after passaging the virus through host pupae. Experimental paradigms differed between the study of Gisder et al. [64] and our own, 
making it difficult to reconcile differences in results, although more in-depth bioinformatics analysis of viral inocula and infected host honey bees might help interpret them.

DWV A-B recombinants have often been reported in honey bees infested by $V$. destructor mites [49-54]. In additional, an A-B recombinant has been found to be more virulent than DWV-A alone, replicating to higher titers when vectored by $V$. destructor mites into pupae [52]. Although Ryabov et al.'s [52] study did not compare the virulence of A or A-B recombinants with B, these studies $[17,40,52]$ nevertheless provide experimental support for the view that DWV-B, or A-B recombinants, are more virulent than DWV-A in adults. Our simultaneous inoculation of pupae with both DWV-A plus DWV-B did not lead to greater viral impact on hosts, compared to DWV-A alone or DWV-B alone. This suggests that viral recombinants may not differ in virulence from parental genotypes in our study, or that the recombinant virus was generated very late in the course of our experiment; thus, putative recombinants with high virulence remained at low titer and had insufficient time to exert an effect on hosts. McMahon et al. [17] similarly found that an inoculum of both DWV-A plus DWV-B was no different in virulence from DWV-B alone in adults, although both showed elevated virulence over DWV-A. These data leave the role of viral recombination between genotypes for viral virulence in DWV open.

We did not find elevated virulence of DWV-B over DWV-A in pupae. Given the higher virulence of $B$ over $A$ in adults that we have formerly detected using related inocula to those employed here [17], the lack of difference in the virulence of DWV-A versus DWV-B in pupae is surprising. We found that DWV-A replicated to slightly higher titers than DWV-B after three days, but that DWV-B replicated to even higher titers than did DWV-A by the time of adult emergence when each was experimentally injected alone into white-eyed pupae. However, DWV-B neither increased pupal mortality nor did it induce greater wing deformities in eclosing adults compared with DWV-A. We hypothesize that the short duration of pupal development (six to seven days from white-eyed pupa to the eclosion of an adult worker honey bee) may have been insufficient for differences in pupal virulence among viral genotypes to become apparent in our experiment. For example, McMahon et al. [17] found that adult mortality in response to DWV experimental infection was most pronounced only at 10 to 20 days p.i.. Varroa destructor mites naturally enter host brood cells during the fifth larval instar stage; immediately after sealing of the brood cell, they commence feeding on the host, which is when they potentially transmit virus during the host's prepupal stage (review in [38]). This would provide a ca. 11-day time window for DWV replication in honey bee pupal hosts [34] (p. 9). To test our hypothesis that our experiment did not extend over a long enough period of time to allow differences in virulence between genotypes A and B of DWV to become apparent, one could inoculate prepupae immediately after cell sealing and follow the pupal fate for longer than in our experiment, which terminated after six to seven days because pupae had already eclosed. However, this experiment would be technically challenging, because prepupae are extremely delicate and difficult to manipulate (pers. obs.).

Alternatively, the virulence of DWV-B in pupae may indeed be no different from that of DWV-A. As the main route of transmission of DWV among honey bees is through the vector $V$. destructor mite [27], which reproduces on host pupae within sealed brood cells, pupal-induced mortality would lead to the failure of mite reproduction and limit viral transmission. This effect would select for the reduced pupal virulence of all of the DWV genotypes [66], and might explain why we found no difference in pupal virulence (mortality, wing deformities) between DWV-A and DWV-B. In support of this view, mathematical models suggest that Acute bee paralysis virus (ABPV), which is another virus transmitted by $V$. destructor between pupae, may be disfavored by $V$. destructor transmission because its virulence is too high in pupae [77,78]; it effectively eliminates itself from host colonies by killing the host and vector before viral transmission is possible. Indeed, our data suggest that both DWV-A and DWV-B possess traits (low virulence in pupae) that allow them potentially to increase in prevalence in honey bee populations, underpinning their emergence across the globe wherever $V$. destructor has invaded A. mellifera populations [58]. 
We found that the pupae from one colony suffered lower mortality than those of the other colony. These data suggest that genetic variance may exist among honey bees in their tolerance to DWV, which is possibly mediated through differences in innate immunity and antiviral defense [79]. Although our experiments were based on pupae from only two colonies, and were not designed to test for genetic variance in the host response to DWV, our results suggest that the topic warrants further study.

DWV injected into white-eyed honey bee pupae has been previously shown to induce wing deformities in resultant adults in a dose-dependent manner [31]. The log-linear relationship they [31] described between viral dose and the deformed wing phenotype predicts between $28 \%$ (for a dose of $10^{2} \mathrm{DWV}$ genome equivalents) and $59 \%$ (for a dose of $10^{4} \mathrm{DWV}$ genome equivalents) wing deformities for our experimental protocol, which is remarkably close to the $60 \%$ elevation in wing deformities we actually recorded. Notwithstanding this dose-response relationship, an open question remains over why DWV does not always induce deformed wings. DWV can be detected around wing buds during pupal development [34] (pp. 109-114), suggesting that its presence at this site may play a role. As primordial wing buds are laid down early in the larval development of holometabolous insects [80], we hypothesize that wing deformation may depend upon the presence or concentration of DWV in pupal wing buds or in unfolding wings during a critical stage or stages of metamorphosis. However, our data do suggest that viral genotype (A versus $\mathrm{B}$ ) is not related to wing deformation in eclosing adults, which is a view shared by Brettell et al. [81].

It has been suggested that the invasion of $V$. destructor into honey bee populations not only led to the emergence of DWV $[19,20]$, but that it also may have selected for a particular DWV variant favored by mite vectoring $[31,66,82]$. DWV-B is a likely candidate variant favored by $V$. destructor transmission. Although first described in 2004 from the Netherlands [33], it is nowadays widespread and at high prevalence in Great Britain $[17,55,56]$ and Germany [18]. It may have formerly been unrecorded or under-recorded, and therefore, its current high prevalence in Europe may be an artefact through a lack of detection in earlier studies. However, DWV-B has increased dramatically in prevalence since its first detection in the USA in 2010 to becoming almost as prevalent as DWV-A across the country in 2016 [61]. Phylogenetic analysis also suggests the rapid population expansion of DWV-B [58]. Our data on pupal virulence support the idea that DWV-B has biological traits allowing it to emerge in honey bees parasitized by $V$. destructor, where it has a major impact on adult honey bee health $[17,40]$ and overwinter survival [18] because of its greater virulence in adult hosts compared to DWV-A. The higher titers of DWV-B in comparison to DWV-A, which is markedly so in adults but also subtly so in pupae, as we show here, also support the idea that DWV-B is emerging, leading to a gradual mixing of genotypes and potentially the generation of recombinants, or even the replacement of DWV-A. If DWV-B is better able to be transmitted by, or even replicate in, $V$. destructor, as suggested by Gisder et al. [64], this might also facilitate its emergence. The potential for the replacement of DWV-A by DWV-B will require additional information on competitive interactions in co-infected hosts, including recombination [52] and the fate of the recombinant virus.

Supplementary Materials: The following are available online at http:/ /www.mdpi.com/1999-4915/11/2/114/s1, Figure S1: NGS read coverage of the experimental inocula across the DWV genome, Figure S2: Genetic variability of the experimental inocula across the DWV genome, Figure S3: IVA DWV-A contig sequences of the DWV inocula and DWV-inoculated pupae, Figure S4: IVA DWV-B contig sequences of the DWV inocula and DWV-inoculated pupae, Figure S5: Alignment of contigs generated by IVA assembly software using NGS datasets, Figure S6: Phylogeny of contigs generated by IVA assembly software using NGS datasets, Figure S7: Titers of DWV-A and DWV-B per honey bee pupa at days zero and three post-inoculation, Figure S8: Survival and wing deformities in treatment groups split by colony of origin, Figure S9: Viral titers per bee in eclosing honey bee adults inoculated with DWV-A and DWV-B, Table S1: Contents of NGS reads of DWV inocula, Table S2: Contents of NGS reads of eclosing adult hosts, Table S3: Comparison of published DWV sequences with our NGS libraries. All of the NGS data files used in this paper are publicly available in the SRA (short read archive) of NCBI, which is accessible under BioProject ID PRJNA515220.

Author Contributions: Conceptualization, V.D.; Methodology, A.T. and Q.V; Software, D.B., A.G.-D., P.K., and C.J.; Validation, A.T., A.G.-D., and R.P.; Formal Analysis, P.T.; Investigation, A.T. and D.B.; Resources, V.D.; Data Curation, D.B.; Writing-Original Draft Preparation, A.T. and R.P.; Writing-Review and Editing, V.D.; Visualization, A.T. and P.T.; Supervision, R.P.; Project Administration, R.P.; Funding Acquisition, R.P. 
Funding: This research was funded by a fellowship of the DBU to A.T., the German Research Foundation (DFG) grant number Pa632/10-1, and iDiv (2013 NGS-Fast Track grant W47004118). We acknowledge the financial support within the funding programme Open Access Publishing by the DFG, administered by Martin Luther University Halle-Wittenberg.

Acknowledgments: We thank Anja Miertsch and Kerstin Gößel for assistance in the laboratory with RNA extractions, qPCRs, and in the apiary, managing honey bee colonies. We are very grateful to Myrsini Natsopoulou, Dino McMahon, and two anonymous referees for their insightful comments, which helped improve the manuscript.

Conflicts of Interest: The authors declare no conflict of interest. The funders had no role in the design of the study; in the collection, analyses, or interpretation of data; in the writing of the manuscript, and in the decision to publish the results.

\section{Appendix A}

Details of RNA extraction and quality control of qPCRs. When testing whether our honey bee source colonies one and two were free of RNA virus infection, we collected 12 adult worker honey bees per colony from the brood nest, crushed them in a plastic RNAse-free mesh bag (BioReba, Reinach, Switzerland) with six $\mathrm{mL}$ of ultrapure diethylpyrocarbonat (DEPC)-treated water after snap-freezing on dry ice, and then recovered $100 \mu \mathrm{L}$ of homogenate from beyond the BioReba mesh for RNA extraction. When screening pupal homogenates (our inocula) for RNA viruses and quantifying DWV titers in them, we crushed three pupae in $500 \mu \mathrm{L}$ of $0.5 \mathrm{M}$ of potassium phosphate buffer (PPB) (pH 8.0) using a plastic pestle, of which $50 \mu \mathrm{L}$ was used for RNA isolation. When quantifying viral titers in adult worker bees arising from inoculation experiments and in pupae at days zero and three p.i., we crushed whole bees individually in $500 \mu \mathrm{L}$ of $0.5 \mathrm{M} \mathrm{PPB}(\mathrm{pH}$ 8.0) using a plastic pestle, of which $100 \mu \mathrm{L}$ were used for RNA isolation. RNA was extracted from bee homogenates using an RNeasy mini kit (Qiagen, Hilden, Germany) following the manufacturer's instructions in a QiaCube robot (Qiagen). cDNA was synthesized from RNA extracts using oligo(dT) 18 primers (Thermo Scientific) and reverse transcriptase (M-MLV and Revertase, Promega, Mannheim, Germany) following the manufacturer's instructions. For cDNA synthesis, 800 ng of RNA were used, after which the resultant cDNA was diluted 1:10 prior to use in qPCR.

We ran quality control checks on each qPCR 96-well reaction plate. To check that the correct template had been amplified, PCR products were denatured for one minute at $95{ }^{\circ} \mathrm{C}$, cooled to $55{ }^{\circ} \mathrm{C}$ for one minute, and then a melting profile was generated from $55{ }^{\circ} \mathrm{C}$ to $95{ }^{\circ} \mathrm{C}\left(0.5{ }^{\circ} \mathrm{C}\right.$ per second increment). qPCRs were repeated for samples whose melting profiles suggested non-specific amplification (broad peak) or an incorrect melting temperature. In addition, a virus-free (negative control) and a virus-infected (positive control) sample were included on each 96-well plate. Apis mellifera $\beta$-actin was also amplified for all of the samples as a honey bee internal reference marker using the primers given in [83] and the same PCR program as for viral detection. PCRs were repeated if the negative and positive controls gave an unexpected signal (positive or negative, respectively), or if $A$. mellifera $\beta$-actin gave a $\mathrm{Ct}>35$, suggesting RNA degradation, error in RNA extraction, or failure in cDNA synthesis.

\section{Appendix B}

Bioinformatics analysis of NGS libraries generated from inocula (DWV-A inoculum and DWV-B inoculum) and virus derived from experimentally inoculated host pupae as they eclosed as adults (individual pupal code: D4-DWV-A and individual pupal code: V4-DWV-B for DWV-A and DWV-B inoculated pupae, respectively). Initial NGS datasets ('DWV-A inoculum' and 'DWV-B inoculum') were filtered in order to exclude A. mellifera, DWV-A, or DWV-B reads so as to explore other viruses or possible contaminants in our inocula. Remaining unmapped reads were de novo assembled into contigs with ABySS [84] using a kmer set at 60, followed by a CAP3 assembly [85] using default parameters. Open reading frames were then predicted by Prodigal $[86,87]$ with the metagenomic option.

After the removal of DWV and Apis mellifera contigs from the NGS datasets of the inocula, searches for similarities between the predicted remaining proteins in our NGS libraries (inoculum DWV-A, 
inoculum DWV-B, D4-DWV-A, and V4-DWV-B) and the NCBI protein collection (nr, version from 03 May 2018, downloaded from ftp:/ / ftp.ncbi.nlm.nih.gov/blast/db) were performed using NCBI blastp [88]. Output was then manually inspected. Apis rhabdovirus 1 (BRV-1) [72,73] was found in both inocula datasets (Table S1) and represents almost full genomes, but was represented by few reads (6113 and 33,735 in inoculum-DWV-A and DWV-B respectively; see Table S1). Other hits were related to bacteria, other viruses, other eukaryote proteins, or unannotated Apis rRNA genes. Finally, only $35,240(0.238 \%)$ reads from the DWV-A inoculum and 20,628 (0.064\%) reads from the DWV-B inoculum remained unassigned after uniquely mapping all of the reads to assembled contigs using Bowtie 2 [69] (Table S1).

In contrast to the DWV inocula, full-length BRV-1 was undetectable in adults that eclosed from experimentally inoculated pupae (Table S2). Furthermore, DWV became more predominant after infection, comprising $43-57 \%$ of reads, compared to only $12-32 \%$ of reads in the original inocula (Table S2). All of the NGS data files are accessible under BioProject ID PRJNA515220.

\section{References}

1. Klein, A.-M.; Vaissiére, B.E.; Cane, J.H.; Steffan-Dewenter, I.; Cunningham, S.A.; Kremen, C.; Tscharntke, T. Importance of pollinators in changing landscapes for world crops. Proc. R. Soc. Lond. B 2007, 274, 303-314. [CrossRef]

2. Hung, K.-L.J.; Kingston, J.M.; Albrecht, M.; Holway, D.A.; Kohn, J.R. The worldwide importance of honey bees as pollinators in natural habitats. Proc. R. Soc. B Biol. Sci. 2018, 285, 20172140. [CrossRef]

3. Aizen, M.A.; Harder, L.D. The global stock of domesticated honey bees is growing slower than agricultural demand for pollination. Curr. Biol. 2009, 19, 915-918. [CrossRef]

4. Potts, S.G.; Imperatriz-Fonseca, V.; Ngo, H.T.; Aizen, M.A.; Biesmeijer, J.C.; Breeze, T.D.; Dicks, L.V.; Garibaldi, L.A.; Hill, R.; Settele, J.; et al. Safeguarding pollinators and their values to human well-being. Nature 2016, 540, 220-229. [CrossRef]

5. Oldroyd, B.P. What's killing American honey bees? PLoS Biol. 2007, 5, e168. [CrossRef]

6. Watanabe, M.E. What's new with honeybees? Bioscience 2009, 59, 1010. [CrossRef]

7. Neumann, P.; Carreck, N.L. Honey bee colony losses. J. Apic. Res. 2010, 49, 1-6. [CrossRef]

8. Vanbergen, A.J.; Initiative, I.P. Threats to an ecosystem service: Pressures on pollinators. Front. Ecol. Environ. 2013, 11, 251-259. [CrossRef]

9. Goulson, D.; Nicholls, E.; Botías, C.; Rotheray, E.L. Bee declines driven by combined stress from parasites, pesticides, and lack of flowers. Science 2015, 347, 1255957. [CrossRef]

10. Highfield, A.C.; El Nagar, A.; Mackinder, L.C.M.; Noël, L.M.-L.J.; Hall, M.J.; Martin, S.J.; Schroeder, D.C. Deformed wing virus implicated in overwintering honeybee colony losses. Appl. Environ. Microbiol. 2009, 75, 7212-7220. [CrossRef]

11. Dainat, B.; Evans, J.D.; Chen, Y.P.; Gauthier, L.; Neumann, P. Dead or alive: Deformed wing virus and Varroa destructor reduce the life span of winter honeybees. Appl. Environ. Microbiol. 2012, 78, 981-987. [CrossRef]

12. Nazzi, F.; Brown, S.P.; Annoscia, D.; Del Piccolo, F.; Di Prisco, G.; Varricchio, P.; Della Vedova, G.; Cattonaro, F.; Caprio, E.; Pennacchio, F. Synergistic parasite-pathogen interactions mediated by host immunity can drive the collapse of honeybee colonies. PLoS Pathog. 2012, 8, e1002735. [CrossRef]

13. Francis, R.M.; Nielsen, S.L.; Kryger, P. Varroa-virus interaction in collapsing honey bee colonies. PLoS ONE 2013, 8, e57540. [CrossRef]

14. Nguyen, B.K.; Ribière, M.; vanEngelsdorp, D.; Snoeck, C.; Saegerman, C.; Kalkstein, A.L.; Schurr, F.; Brostaux, Y.; Faucon, J.-P.; Haubruge, E. Effects of honey bee virus prevalence, Varroa destructor load and queen condition on honey bee colony survival over the winter in Belgium. J. Apic. Res. 2011, 50, 195-202. [CrossRef]

15. Budge, G.E.; Pietravalle, S.; Brown, M.; Laurenson, L.; Jones, B.; Tomkies, V.; Delaplane, K.S. Pathogens as predictors of honey bee colony strength in England and Wales. PLoS ONE 2015, 10, e0133228. [CrossRef]

16. Di Prisco, G.; Annoscia, D.; Margiotta, M.; Ferrara, R.; Varricchio, P.; Zanni, V.; Caprio, E.; Nazzi, F.; Pennacchio, F. A mutualistic symbiosis between a parasitic mite and a pathogenic virus undermines honey bee immunity and health. Proc. Natl. Acad. Sci. USA 2016, 113, 3203-3208. [CrossRef] 
17. McMahon, D.P.; Natsopoulou, M.E.; Doublet, V.; Fürst, M.; Weging, S.; Brown, M.J.F.; Gogol-Döring, A.; Paxton, R.J. Elevated virulence of an emerging viral genotype as a driver of honeybee loss. Proc. R. Soc. Lond. B Biol. Sci. 2016, 283, 20160811. [CrossRef]

18. Natsopoulou, M.E.; McMahon, D.P.; Doublet, V.; Frey, E.; Rosenkranz, P.; Paxton, R.J. The virulent, emerging genotype B of Deformed wing virus is closely linked to overwinter honeybee worker loss. Sci. Rep. 2017, 7, 5242. [CrossRef]

19. Martin, S.J.; Highfield, A.C.; Brettell, L.; Villalobos, E.M.; Budge, G.E.; Powell, M.; Nikaido, S.; Schroeder, D.C. Global honey bee viral landscape altered by a parasitic mite. Science 2012, 336, 1304-1306. [CrossRef]

20. Mondet, F.; de Miranda, J.R.; Kretzschmar, A.; Le Conte, Y.; Mercer, A.R. On the front line: Quantitative virus dynamics in honeybee (Apis mellifera L.) colonies along a new expansion front of the parasite Varroa destructor. PLoS Pathog. 2014, 10, e1004323. [CrossRef]

21. Bailey, L.; Ball, B.V. Honey Bee Pathology, 2nd ed.; Academic Press: Cambridge, MA, USA, 1991.

22. Chen, Y.; Pettis, J.S.; Feldlaufer, M.F. Detection of multiple viruses in queens of the honey bee Apis mellifera L. J. Invertebr. Pathol. 2005, 90, 118-121. [CrossRef]

23. Chen, Y.; Evans, J.D.; Feldlaufer, M. Horizontal and vertical transmission of viruses in the honey bee, Apis mellifera. J. Invertebr. Pathol. 2006, 92, 152-159. [CrossRef]

24. Yue, C.; Genersch, E. RT-PCR analysis of Deformed wing virus in honeybees (Apis mellifera) and mites (Varroa destructor). J. Gen. Virol. 2005, 86, 3419-3424. [CrossRef]

25. Yue, C.; Schröder, M.; Gisder, S.; Genersch, E. Vertical-transmission routes for Deformed wing virus of honeybees (Apis mellifera). J. Gen. Virol. 2007, 88, 2329-2336. [CrossRef]

26. De Miranda, J.R.; Fries, I. Venereal and vertical transmission of Deformed wing virus in honeybees (Apis mellifera L.). J. Invertebr. Pathol. 2008, 98, 184-189. [CrossRef]

27. De Miranda, J.R.; Genersch, E. Deformed wing virus. J. Invertebr. Pathol. 2010, 103, S48-S61. [CrossRef]

28. Ball, B.V. Varroa jacobsoni as a virus vector. In Present Status of Varroatosis in Europe and Progress in the Varroa Mite Control; Cavalloro, R., Ed.; ECSC-EEC-EAEC of the European Economic Commission: Luxembourg, 1989; pp. 241-244.

29. Nordström, S. Distribution of Deformed wing virus within honey bee (Apis mellifera) brood cells infested with the ectoparasitic mite Varroa destructor. Exp. Appl. Acarol. 2003, 29, 293-302. [CrossRef]

30. Gisder, S.; Aumeier, P.; Genersch, E. Deformed wing virus: Replication and viral load in mites (Varroa destructor). J. Gen. Virol. 2009, 90, 463-467. [CrossRef]

31. Möckel, N.; Gisder, S.; Genersch, E. Horizontal transmission of Deformed wing virus: Pathological consequences in adult bees (Apis mellifera) depend on the transmission route. J. Gen. Virol. 2011, 92, 370-377. [CrossRef]

32. Annoscia, D.; Brown, S.; Di Prisco, G.; De Paoli, E.; Del Fabbro, S.; Zanni, V.; Galbraith, D.; Caprio, E.; Grozinger, C.M.; Pennacchio, F.; et al. Haemolymph removal by the parasite Varroa destructor can trigger the proliferation of the Deformed wing virus in mite infested bees (Apis mellifera), contributing to enhanced pathogen virulence. bioRxiv 2018. [CrossRef]

33. Ongus, J.R.; Peters, D.; Bonmatin, J.M.; Bengsch, E.; Vlak, J.M.; van Oers, M.M. Complete sequence of a picorna-like virus of the genus Iflavirus replicating in the mite Varroa destructor. J. Gen. Virol. 2004, 85, 3747-3755. [CrossRef] [PubMed]

34. Aupperle, H.; Genersch, E. Diagnostischer Farbatlas der Bienenepathologie. Diagnostic Color Atlas of Bee Pathology; Verlag LABOKLIN: Bad Kissingen, Germany, 2016; p. 191.

35. Erban, T.; Harant, K.; Hubalek, M.; Vitamvas, P.; Kamler, M.; Poltronieri, P.; Tyl, J.; Markovic, M.; Titera, D. In-depth proteomic analysis of Varroa destructor: Detection of DWV-complex, ABPV, VdMLV and honeybee proteins in the mite. Sci. Rep. 2015, 5, 13907. [CrossRef]

36. Ball, B.V.; Allen, M.F. The prevalence of pathogens in honey bee (Apis mellifera) colonies infested with the parasitic mite Varroa jacobsoni. Ann. Appl. Biol. 1988, 113, 237-244. [CrossRef]

37. Shen, M.; Cui, L.; Ostiguy, N.; Cox-Foster, D. Intricate transmission routes and interactions between picorna-like viruses (Kashmir bee virus and Sacbrood virus) with the honeybee host and the parasitic varroa mite. J. Gen. Virol. 2005, 86, 2281-2289. [CrossRef] [PubMed]

38. Rosenkranz, P.; Aumeier, P.; Ziegelmann, B. Biology and control of Varroa destructor. J. Invertebr. Pathol. 2010, 103, S96-S119. [CrossRef] 
39. Natsopoulou, M.E.; McMahon, D.P.; Paxton, R.J. Parasites modulate within-colony activity and accelerate the temporal polyethism schedule of a social insect, the honey bee. Behav. Ecol. Sociobiol. 2016, 70, 1019-1031. [CrossRef] [PubMed]

40. Benaets, K.; Van Geystelen, A.; Cardoen, D.; De Smet, L.; de Graaf, D.C.; Schoofs, L.; Larmuseau, M.H.D.; Brettell, L.E.; Martin, S.J.; Wenseleers, T. Covert Deformed wing virus infections have long-term deleterious effects on honeybee foraging and survival. Proc. R. Soc. B Biol. Sci. 2017, 284, 20162149. [CrossRef] [PubMed]

41. Allen, M.; Ball, B. The incidence and world distribution of honey bee viruses. Bee World 1996, 77, 141-162. [CrossRef]

42. Lanzi, G.; de Miranda, J.R.; Boniotti, M.B.; Cameron, C.E.; Lavazza, A.; Capucci, L.; Camazine, S.M.; Rossi, C. Molecular and biological characterization of Deformed wing virus of honeybees (Apis mellifera L.). J. Virol. 2006, 80, 4998-5009. [CrossRef]

43. Škubník, K.; Nováček, J.; Füzik, T.; Přidal, A.; Paxton, R.J.; Plevka, P. Structure of Deformed wing virus, a major honey bee pathogen. Proc. Natl. Acad. Sci. USA 2017, 114, 3210-3215. [CrossRef] [PubMed]

44. Lamp, B.; Url, A.; Seitz, K.; Eichhorn, J.; Riedel, C.; Sinn, L.J.; Indik, S.; Köglberger, H.; Rümenapf, T. Construction and rescue of a molecular clone of Deformed wing virus (DWV). PLoS ONE 2016, 11, e0164639. [CrossRef] [PubMed]

45. Tong, S.; Revill, P. Overview of Hepatitis B viral replication and genetic variability. J. Hepatol. 2016, 64, S4-S16. [CrossRef] [PubMed]

46. Mordecai, G.J.; Brettell, L.E.; Martin, S.J.; Dixon, D.; Jones, I.M.; Schroeder, D.C. Superinfection exclusion and the long-term survival of honey bees in Varroa-infested colonies. ISME J. 2015, 10, 1182-1191. [CrossRef] [PubMed]

47. Mordecai, G.J.; Wilfert, L.; Martin, S.J.; Jones, I.M.; Schroeder, D.C. Diversity in a honey bee pathogen: First report of a third master variant of the Deformed wing virus quasispecies. ISME J. 2016, 10, 1264-1273. [CrossRef]

48. Kevill, J.; Highfield, A.; Mordecai, G.; Martin, S.; Schroeder, D. ABC assay: Method development and application to quantify the role of three DWV master variants in overwinter colony losses of European honey bees. Viruses 2017, 9, 314. [CrossRef] [PubMed]

49. Moore, J.; Jironkin, A.; Chandler, D.; Burroughs, N.; Evans, D.J.; Ryabov, E.V. Recombinants between Deformed wing virus and Varroa destructor virus-1 may prevail in Varroa destructor-infested honeybee colonies. J. Gen. Virol. 2011, 92, 156-161. [CrossRef] [PubMed]

50. Zioni, N.; Soroker, V.; Chejanovsky, N. Replication of Varroa destructor virus 1 (VDV-1) and a Varroa destructor virus 1-Deformed wing virus recombinant (VDV-1-DWV) in the head of the honey bee. Virology 2011, 417, 106-112. [CrossRef]

51. Wang, H.; Xie, J.; Shreeve, T.G.; Ma, J.; Pallett, D.W.; King, L.A.; Possee, R.D. Sequence recombination and conservation of Varroa destructor virus-1 and Deformed wing virus in field collected honey bees (Apis mellifera). PLOS ONE 2013, 8, e74508. [CrossRef]

52. Ryabov, E.V.; Wood, G.R.; Fannon, J.M.; Moore, J.D.; Bull, J.C.; Chandler, D.; Mead, A.; Burroughs, N.; Evans, D.J. A virulent strain of Deformed wing virus (DWV) of honeybees (Apis mellifera) prevails after Varroa destructor-mediated, or in vitro, transmission. PLoS Pathog. 2014, 10, e1004230. [CrossRef]

53. Cornman, R.S. Relative abundance of Deformed wing virus, Varroa destructor virus 1, and their recombinants in honey bees (Apis mellifera) assessed by kmer analysis of public RNA-seq data. J. Invertebr. Pathol. 2017, 149, 44-50. [CrossRef]

54. Dalmon, A.; Desbiez, C.; Coulon, M.; Thomasson, M.; Le Conte, Y.; Alaux, C.; Vallon, J.; Moury, B. Evidence for positive selection and recombination hotspots in Deformed wing virus (DWV). Sci. Rep. 2017, 7, 41045. [CrossRef] [PubMed]

55. Fürst, M.A.; McMahon, D.P.; Osborne, J.L.; Paxton, R.J.; Brown, M.J.F. Disease associations between honeybees and bumblebees as a threat to wild pollinators. Nature 2014, 506, 364-366. [CrossRef] [PubMed]

56. McMahon, D.P.; Fürst, M.A.; Caspar, J.; Theodorou, P.; Brown, M.J.F.; Paxton, R.J. A sting in the spit: Widespread cross-infection of multiple RNA viruses across wild and managed bees. J. Anim. Ecol. 2015, 84, 615-624. [CrossRef] [PubMed]

57. Radzevičiūtė, R.; Theodorou, P.; Husemann, M.; Japoshvili, G.; Kirkitadze, G.; Zhusupbaeva, A.; Paxton, R.J. Replication of honey bee-associated RNA viruses across multiple bee species in apple orchards of Georgia, Germany and Kyrgyzstan. J. Invertebr. Pathol. 2017, 146, 14-23. [CrossRef] [PubMed] 
58. Wilfert, L.; Long, G.; Leggett, H.C.; Schmid-Hempel, P.; Butlin, R.; Martin, S.J.M.; Boots, M. Deformed wing virus is a recent global epidemic in honeybees driven by Varroa mites. Science 2016, 351, 594-597. [CrossRef]

59. Ongus, J.R.; Fombong, A.T.; Irungu, J.; Masiga, D.; Raina, S. Prevalence of common honey bee pathogens at selected apiaries in Kenya, 2013/2014. Int. J. Trop. Insect Sci. 2018, 38, 58-70. [CrossRef]

60. Strauss, U.; Human, H.; Gauthier, L.; Crewe, R.M.; Dietemann, V.; Pirk, C.W.W. Seasonal prevalence of pathogens and parasites in the savannah honeybee (Apis mellifera scutellata). J. Invertebr. Pathol. 2013, 114, 45-52. [CrossRef]

61. Ryabov, E.V.; Childers, A.K.; Chen, Y.; Madella, S.; Nessa, A.; van Engelsdorp, D.; Evans, J.D. Recent spread of Varroa destructor virus-1, a honey bee pathogen, in the United States. Sci. Rep. 2017, 7, 17447. [CrossRef]

62. Roberts, J.M.K.; Anderson, D.L.; Durr, P.A. Absence of Deformed wing virus and Varroa destructor in Australia provides unique perspectives on honeybee viral landscapes and colony losses. Sci. Rep. 2017, 7, 6925. [CrossRef]

63. Schmid-Hempel, P. Evolutionary Parasitology; Oxford University Press: Oxford, UK, 2011; p. 516.

64. Gisder, S.; Möckel, N.; Eisenhardt, D.; Genersch, E. In vivo evolution of viral virulence: Switching of Deformed wing virus between hosts results in virulence changes and sequence shifts. Environ. Microbiol. 2018. [CrossRef]

65. Winston, M.L. The Biology of the Honey Bee; Harvard University Press: Cambridge, MA, USA, 1987; p. 281.

66. McMahon, D.P.; Wilfert, L.; Paxton, R.J.; Brown, M.J.F. Chapter Eight-Emerging viruses in bees: From molecules to ecology. In Advances in Virus Research; Malmstrom, C.M., Ed.; Academic Press: Cambridge, MA, USA, 2018; Volume 101, pp. 251-291.

67. Locke, B.; Forsgren, E.; Fries, I.; de Miranda, J.R. Acaricide treatment affects viral dynamics in Varroa destructor-infested honey bee colonies via both host physiology and mite control. Appl. Environ. Microbiol. 2012, 78, 227-235. [CrossRef] [PubMed]

68. De Miranda, J.R.; Bailey, L.; Ball, B.V.; Blanchard, P.; Budge, G.; Chejanovsky, N.; Chen, Y.-P.; Gauthier, L.; Genersch, E.; de Graaf, D.; et al. Standard methods for virus research in Apis mellifera. J. Apic. Res. 2013, 52, 1-56. [CrossRef]

69. Langmead, B.; Salzberg, S.L. Fast gapped-read alignment with Bowtie 2. Nat. Methods 2012, 9, 357-359. [CrossRef] [PubMed]

70. Hunt, M.; Gall, A.; Ong, S.H.; Brener, J.; Ferns, B.; Goulder, P.; Nastouli, E.; Keane, J.A.; Kellam, P.; Otto, T.D. IVA: Accurate de novo assembly of RNA virus genomes. Bioinformatics 2015, 31, 2374-2376. [CrossRef] [PubMed]

71. Guindon, S.; Gascuel, O. A simple, fast, and accurate algorithm to estimate large phylogenies by maximum likelihood. Syst. Biol. 2003, 52, 696-704. [CrossRef] [PubMed]

72. Levin, S.; Galbraith, D.; Sela, N.; Erez, T.; Grozinger, C.M.; Chejanovsky, N. Presence of Apis rhabdovirus-1 in populations of pollinators and their parasites from two Continents. Front. Microbiol. 2017, 8, 2482. [CrossRef]

73. Remnant, E.J.; Shi, M.; Buchmann, G.; Blacquière, T.; Holmes, E.C.; Beekman, M.; Ashe, A. A diverse range of novel RNA viruses in geographically distinct honey bee populations. J. Virol. 2017, 91, e00158-17. [CrossRef]

74. Bates, D.; Mächler, M.; Bolker, B.; Walker, S. Fitting linear mixed-effects models using lme4. J. Stat. Softw. 2015, 1, 1-48. [CrossRef]

75. Hothorn, T.; Bretz, F.; Westfall, P. Simultaneous inference in general parametric models. Biom. J. 2008, 50, 346-363. [CrossRef]

76. Team, R.C. R: A Language and Environment for Statistical Computing; R Foundation for Statistical Computing: Vienna, Austria, 2014.

77. Martin, S.J. The role of Varroa and viral pathogens in the collapse of honeybee colonies: A modelling approach. J. Appl. Ecol. 2001, 38, 1082-1093. [CrossRef]

78. Sumpter, D.J.T.; Martin, S.J. The dynamics of virus epidemics in varroa-infested honey bee colonies. J. Anim. Ecol. 2004, 73, 51-63. [CrossRef]

79. Brutscher, L.M.; Daughenbaugh, K.F.; Flenniken, M.L. Antiviral defense mechanisms in honey bees. Curr. Opin. Insect Sci. 2015, 10, 71-82. [CrossRef] [PubMed]

80. Gullan, P.J.; Cranston, P.S. The Insects: An Outline in Entomology, 5th ed.; Blackwell: Oxford, UK, $2014 ;$ p. 624.

81. Brettell, L.; Mordecai, G.; Schroeder, D.; Jones, I.; da Silva, J.; Vicente-Rubiano, M.; Martin, S. A comparison of Deformed wing virus in deformed and asymptomatic honey bees. Insects 2017, 8, 28. [CrossRef] 
82. Neumann, P.; Yañez, O.; Fries, I.; de Miranda, J.R. Varroa invasion and virus adaptation. Trends Parasitol. 2012, 28, 353-354. [CrossRef] [PubMed]

83. Forsgren, E.; Locke, B.; Semberg, E.; Laugen, A.T.; Miranda, J.R.D. Sample preservation, transport and processing strategies for honeybee RNA extraction: Influence on RNA yield, quality, target quantification and data normalization. J. Virol. Methods 2017. [CrossRef]

84. Simpson, J.T.; Wong, K.; Jackman, S.D.; Schein, J.E.; Jones, S.J.M.; Birol, İ. ABySS: A parallel assembler for short read sequence data. Genome Res. 2009, 19, 1117-1123. [CrossRef]

85. Huang, X.; Madan, A. CAP3: A DNA sequence assembly program. Genome Res. 1999, 9, 868-877. [CrossRef]

86. Hyatt, D.; Chen, G.-L.; LoCascio, P.F.; Land, M.L.; Larimer, F.W.; Hauser, L.J. Prodigal: Prokaryotic gene recognition and translation initiation site identification. BMC Bioinform. 2010, 11, 119. [CrossRef]

87. Hyatt, D.; LoCascio, P.F.; Hauser, L.J.; Uberbacher, E.C. Gene and translation initiation site prediction in metagenomic sequences. Bioinformatics 2012, 28, 2223-2230. [CrossRef]

88. Altschul, S.F.; Gish, W.; Miller, W.; Myers, E.W.; Lipman, D.J. Basic local alignment search tool. J. Mol. Biol. 1990, 215, 403-410. [CrossRef]

(C) 2019 by the authors. Licensee MDPI, Basel, Switzerland. This article is an open access article distributed under the terms and conditions of the Creative Commons Attribution (CC BY) license (http://creativecommons.org/licenses/by/4.0/). 